\title{
Heterogeneity of Karyotypes in Turner Syndrome
}

\section{Sunetra Mondal ${ }^{1} \cdot$ Rana Bhattacharjee $^{1} \cdot$ Subhankar Chowdhury ${ }^{1} \cdot$ Satinath Mukhopadhyay ${ }^{1}$}

Received: 3 February 2020 / Accepted: 11 June 2020 / Published online: 4 July 2020

(C) Dr. K C Chaudhuri Foundation 2020

To the Editor: Turner syndrome (TS) is one of the commonest chromosomal disorders affecting 25-50 per 100,000 females globally [1]. The diagnosis of TS requires the presence of characteristic physical features in phenotypic females with complete or partial absence or structural abnormality of one X chromosome, with or without cell line mosaicism [2]. Several karyotypes showing loss or fragmentation of one $\mathrm{X}$ chromosome are considered under the purview of TS. The true karyotype distribution of TS in India is largely unknown due to paucity of published literature in this area [3]. We conducted a cross-sectional study to document the prevalence of different karyotypic variants in the largest cohort of TS from India reported till date. The percentage distribution of most variants corroborated with the worldwide literature. Majority $(44.1 \%)$ were classical TS followed by karyotypes having $46, \mathrm{X}, \mathrm{XXq}$ either in all the cells or as part of mosaicism with 45,XO containing cell lines [karyotypes containing isochromosome $\mathrm{Xq}=25$ (24.5\%) of which $46, \mathrm{X}, \mathrm{iXq}=11,45, \mathrm{X} / 46, \mathrm{X}, \mathrm{iXq}=12$ and 45,X/46,XX/ $46, \mathrm{X}, \mathrm{iXq}=2]$ and $\mathrm{XO} / \mathrm{XX}$-mosaics $(17.6 \%)$. More than half $(56 \%)$ of the isochromosome-Xq were mosaics with $\mathrm{XO}$ cell lines with 12 cases having mosaicism with monosomy $\mathrm{X}$ and two cases having complex mosaicism involving three cell lines, i.e., 45,X0, 46,XX and 46,X,iXq. Most of the girls with mosaic isochromosome-Xq (mosaicism of $46, \mathrm{X}, \mathrm{iXq}$ with XO or complex mosaicisms, $n=$ 14) had isodicentric-Xq (11 out of 14); the commonest breakpoint was q21 followed by q10. Interestingly, all of

Satinath Mukhopadhyay

satinath.mukhopadhyay@gmail.com

1 Department of Endocrinology and Metabolism, Institute of Post Graduate Medical Education and Research (IPGME\&R) and SSKM Hospital, Ronald Ross Building, 4th Floor, Bhowanipore,

Kolkata, West Bengal 700020, India those with pure isochromosomes $(46, \mathrm{X}, \mathrm{iXq})$ had a breakpoint at q10. Four patients exhibited mosaicism of XO cell lines with marker chromosomes detected on karyotyping of the peripheral blood leucocytes. For these patients, an interphase FISH with $\mathrm{X}$ and $\mathrm{Y}$ chromosomal probes was done; in three subjects, marker chromosome had originated from the $\mathrm{X}$ chromosome; one patient had a $\mathrm{Y}$ chromosomal origin. Our study also revealed a number of extremely rare karyotypes, i.e., isochromosome-Xp and isodicentric chromosome Yp, rarely reported in the published world literature on TS. The prevalence of different karyotypic variants in TS may have ethnic differences, with a prevalence of isochromosomes and isodicentric chromosomes in India.

\section{Compliance with Ethical Standards}

Ethics Committee Approval Approval for the current project was obtained from the Institutional Ethics Committee of IPGME\&R, Kolkata vide memo no: IPGME\&R/IEC/2017/098.

Conflict of Interest None.

\section{References}

1. Bondy CA. Care of girls and women with turner syndrome: a guideline of the Turner Syndrome Study Group. J Clin Endocrinol Metab. 2007;92:10-25.

2. Wolff DJ, Van Dyke DL, Powell CM. Laboratory guideline for Turner syndrome. Genet Med. 2010;12:52-5.

3. Gravholt $\mathrm{CH}$, Andersen $\mathrm{NH}$, Conway GS, et al. Clinical practice guidelines for the care of girls and women with Turner syndrome: Proceedings from the 2016 Cincinnati International Turner Syndrome Meeting. Eur J Endocrinol. 2017;177:G1-70.

Publisher's Note Springer Nature remains neutral with regard to jurisdictional claims in published maps and institutional affiliations. 